\title{
Call for papers: Symposium on Tautomers and Biology, American Chemical Society National Meeting, Boston, MA, USA August 2010
}

\author{
Yvonne C. Martin • Terry R. Stouch
}

Received: 11 January 2010/Accepted: 13 January 2010/Published online: 29 January 2010

(C) Springer Science+Business Media B.V. 2010

Tautomerism is possible for approximately one quarter of biologically interesting small molecules such as xenobiotics, enzyme substrates or cofactors, and biological mediators. Tautomerism complicates investigations into enzyme mechanisms and structure-activity relationships as well as such simple calculations as $\mathrm{p} K_{\mathrm{a}}$, octanol-water $\log P$, and molecular similarity. The objective of this symposium is to showcase the many facets of tautomerism. Examples of appropriate submissions would be observations of the form of a tautomeric molecule bound to a macromolecule, measurements and calculations of tautomeric equilibrium constants in water and non-aqueous solvents, strategies to enumerate tautomers for applications such as molecular docking and pharmacophore perception, investigations of enzyme mechanisms that involve tautomerism, and challenges to data base and cheminformatic handling of tautomers. Deadline for submission of abstracts is March 30, 2010 and can be done at www.acs.org/meetings.
Y. C. Martin

Lexicon Pharmaceuticals, Princeton, NJ, USA

T. R. Stouch $(\bowtie)$

Journal of Computer-Aided Molecular Design, West Windsor, NJ, USA

e-mail: tstouch@gmail.com 
